\title{
Isolation, Growth and Identification of Chlorpyrifos Degrading Bacteria from Agricultural Soil in Anambra State, Nigeria
}

\author{
Ifediegwu, M.C. ${ }^{1}$, Agu, K.C. ${ }^{1,}{ }^{*}$, Awah, N.S. ${ }^{1}$, Mbachu, A.E. ${ }^{1}$, Okeke, C.B. ${ }^{1}$, Anaukwu, C.G. ${ }^{1}$, Uba, P.O. ${ }^{1}$, \\ Ngenegbo, U.C. ${ }^{2}$, Nwankwo, C.M. ${ }^{3}$ \\ ${ }^{1}$ Department of Applied Microbiology and Brewing, Faculty of Biosciences, Nnamdi Azikiwe University, Nigeria \\ ${ }^{2}$ Department of Parasitology and Entomology, Faculty of Biosciences, Nnamdi Azikiwe University, Nigeria \\ ${ }^{3}$ Department of Science Laboratory Technology, School of Applied Science and Technology, Federal Polytechnic Oko, Nigeria
}

Copyright $(\subset 2015$ by authors, all rights reserved. Authors agree that this article remains permanently open access under the terms of the Creative Commons Attribution License 4.0 International License

\begin{abstract}
The extensive use of pesticides is one of the major causes of pollution of soil and water environments. The current method for removing such contaminants from the environment through biodegradation has been shown to be more effective than any other method. Three pesticide degrading bacteria were isolated and identified through cultural and biochemical tests as strains of Pseudomonas aeruginosa, Serretia marcescens and Klebsiella oxytoca. Their growth in mineral salt medium supplemented with $20 \mathrm{mg} / \mathrm{l}$ of Chlorpyrifos was monitored at optical density of $600 \mathrm{~nm}$. The result showed that Pseudomonas aeruginosa had maximum growth in ten days, while Serretia marcescens and Klebsiella oxytoca recorded highest growth after six days of incubation. HPLC analysis of the residual Chlorpyrifos after 14 days incubation showed that Pseudomonas aeruginosa was able to degrade $60 \%$ of the pesticide; Klebsiella oxytoca degraded 54\%, while Serretia marcescens had 53\% reduction of the pesticide concentration in the mineral salt medium. The results of this research indicated that the isolated bacteria can be used for bioremediation of Chlorpyrifos contaminated soil and water ecosystems.
\end{abstract}

Keywords Isolation, Bacteria, Biodegradation, Chlorpyrifos, Pollutants, Agricultural Soil

\section{Introduction}

Pesticide application on agricultural soil is now a common practice and is an important factor of integrated pest management (IPM) strategies $^{5}$. Some of these pesticides persist in the soil to form pollutants which may occasionally lead to surface and groundwater contamination. One of such pesticides is Chlorpyrifos, a widely used organophosphate insecticide ${ }^{3}$.
Chlorpyrifos is a broad-spectrum, moderately toxic insecticide that has been widely used in the prevention of both agricultural pests and urban public health pests ${ }^{15}$. It was introduced in 1965 by Dow Chemical Company India ${ }^{1}$. It has large blights on public health and environment resulting from its long residual period in soil and water ${ }^{7}$. The environmental fate of Chlorpyrifos has been studied extensively, and the reported half-life in soil varies from 10 to120 days, with 3,5,6-trichloro-2-pyridinol (TCP) as the major degradation product ${ }^{11}$. The manufacture and formulation process of Chlorpyrifos also generate waste that contains the compound, and this has to be treated by physicochemical or biological means ${ }^{3}$.

Bioremediation is an environmental clean-up technique involving the use of naturally occurring microorganisms in the decontamination process $^{17-19}$. The bioremediation of organophosphorous pesticides by soil microorganisms has been reported by many workers ${ }^{13}$. Singh et al. (2004) isolated Enterobacter B-14, a strain which could degrade Chlorpyrifos. Yang et al. (2006) and Li et al. (2007) isolated Stenotrophomonas species and Sphingomonas species respectively, which could utilize Chlorpyrifos as the only source of carbon and phosphorous.

The first step in dealing with pollution caused by Chlorpyrifos is the isolation and screening of microbial species that can degrade the pesticide effectively.

The main objective of this study is to isolate and identify Chlorpyrifos utilizing bacteria from agricultural soil using an enrichment culture technique.

This research was aimed at isolating Chlorpyrifos degrading bacteria from contaminated soil, and determining their growth response in mineral salt medium supplemented with Chlorpyrifos.

\section{Materials and Methods}




\subsection{Pesticide Used}

Commercial grade insecticide Chlorpyrifos with $100 \mathrm{mg} / \mathrm{L}$ concentration was obtained from Agricultural Development Programme (ADP) Awka, Anambra State Nigeria.

\subsection{Media}

The Mineral Salt Medium (MSM) used contain the following (in gram per litre): $2.4 \mathrm{~g}$ of $\mathrm{KH}_{2} \mathrm{PO}_{4}, 1.2 \mathrm{~g}$ of $\mathrm{K}_{2} \mathrm{HPO}_{4}, 0.5 \mathrm{~g}$ of $\mathrm{NH}_{4} \mathrm{NO}_{3}, 0.1 \mathrm{~g}$ of $\mathrm{MgSO}_{4} .7 \mathrm{H}_{2} \mathrm{O}, 0.02 \mathrm{~g}$ of $\mathrm{Ca}\left(\mathrm{NO}_{3}\right)_{2}, 0.005 \mathrm{~g}$ of $\mathrm{Fe}\left(\mathrm{SO}_{4}\right)_{3}$. $1 \mathrm{ml}$ of trace metal solution ${ }^{10}$. Agar-agar, Urea agar, Nutrient agar, Simon Citrate agar, MacConkey agar, and Nutrient broth were also used during the isolation and identification of Chlorpyrifos degrading bacteria.

\subsection{Sample Collection}

The rice growing fields in Anaku, Omor, and Igbakwu towns in Ayamelum Local Government Area of Anambra State, Nigeria; which have ten years history of Chlorpyrifos use in pest control were selected for this study. In each of the three farms, soil samples were collected randomly from $12-15 \mathrm{~cm}$ from four corners in $6-8 \mathrm{~m}$ apart, and from the centre of the farms. The soil samples were thoroughly mixed; plant debris sorted out, and put into polyethylene bags. The samples were transferred immediately to the laboratory for analysis.

\subsection{Isolation of Chlorpyrifos Degrading Bacteria}

Chlorpyrifos degrading bacteria were isolated from the soil samples by the enrichment culture technique on mineral salt medium, using Chlorpyrifos as the sole source of carbon as described by Zhu et al., (2010). The enrichment preparation comprised of $10 \mathrm{mg} / \mathrm{L}$ Chlorpyrifos in $100 \mathrm{ml}$ of the mineral salt medium in $250 \mathrm{ml}$ Erlenmeyer's flask. This was autoclaved at $121^{\circ} \mathrm{C}$ for 15 mins before adding $5 \mathrm{~g}$ of the soil sample. The flasks were incubated in a rotary shaker at 120 revolutions per minute (rpm) and $30^{\circ} \mathrm{C}$ for 7 days. After incubation, $1 \mathrm{ml}$ of the culture was inoculated on Chlorpyrifos mineral salt agar, and the plates incubated at $30^{\circ} \mathrm{C}$ for 48hours. The Chlorpyrifos mineral salt agar comprised of mineral salt medium, $1.5 \%$ agar-agar, $1 \%$ Sodium Citrate, $0.5 \%$ methanol (solvent carrier for pesticide), and $10 \mathrm{mg} / \mathrm{L}$ Chlorpyrifos ${ }^{14}$. Three morphologically distinct bacterial growths (A, B and C) on the agar were selected and sub-cultured repeatedly until pure cultures were obtained. The pure cultures were stored in Chlorpyrifos mineral salt agar slant at $4^{\circ} \mathrm{C}$ for further studies.

\subsection{Identification of the Isolates}

The three bacterial isolates grown on Chlorpyrifos agar were subjected to physiological and biochemical tests. The tests carried out include: Gram staining, catalase test, citrate utilization, oxidase test, indole production, motility, sugar fermentation, methyl-red test, nitrate reduction, starch hydrolysis, Voges-Proskeur test and hydrogen sulphide production. Identification was based on recommendations of Gerhard et al., (1981), and then using Bergey's Manual of Determinative Bacteriology for confirmation.

\subsection{Growth of the Isolates and Biodegradation of Chlorpyrifos in Liquid Culture}

The inoculum used for all the experiments was prepared by growing the bacterial isolates in separate $250 \mathrm{ml}$ Erlenmeyer flask containing $50 \mathrm{ml}$ of mineral salt medium (MSM) at 120 revolutions per minute (rpm) and $37^{\circ} \mathrm{C}$ on a rotary shaker for 24 hours. $1 \mathrm{ml}$ of the 24 hour culture containing approximately $1.1 \times 10^{4} \mathrm{CFU} / \mathrm{ml}$ (determined by viable count method) was used as inoculum. This was used to inoculate $250 \mathrm{ml}$ flasks containing $100 \mathrm{ml} \mathrm{MSM}$ and $20 \mathrm{ml} / \mathrm{L}$ of Chlorpyrifos in triplicate. The un-inoculated flask was used as a control. The flasks were incubated in a rotary shaker at $120 \mathrm{rpm}$ and $30^{\circ} \mathrm{C}$ for 14 days.

The growth (optical density) of the isolates were determined at intervals of $0,2,4,6,8,10,12$, and 14 days; using Spectrophotometer (model PD 303 UV-VIS) at $600 \mathrm{~nm}$.

\subsection{Chlorpyrifos Extraction and HPLC Analysis}

After 14 days incubation, $5 \mathrm{ml}$ of the culture was taken from each flask and was placed in centrifuge tubes. This portion of the culture was extracted twice with equal volume of ethyl acetate as the extracting reagent by centrifuging at $150 \mathrm{rpm}$ for 20 minutes. The ethyl acetate with residual Chlorpyrifos was filtered through Whatman No 1 filter paper.

An Agilent FS720 High Performance Liquid Chromatography (HPLC), model SPD-10A, UV-VIS DETECTOR, equipped with tandem reverse phase cartridge column, (C-18) was used to analyse the residual Chlorpyrifos in the culture. The tanden reverse phase cartridge column was fitted at a temperature program of $170^{\circ} \mathrm{C}$ for 30 seconds at a flow rate of $0.8 \mathrm{ml} / \mathrm{min}$ at $25^{\circ} \mathrm{C}$. The retention time was 15 seconds, while the detection limit was $20 \mu \mathrm{g} / \mathrm{L}$ in aqueous phase for Chlorpyrifos.

The concentration of Chlorpyrifos pesticide was determined by removing $1 \mathrm{ml}$ of the filtrate and transferring into $15 \mathrm{ml}$ high performance liquid chromatography vial containing $60 \%$ methanol and $40 \%$ water $(3: 2)$ and analysed by HPLC. Calibration curves from 0 to $100 \mathrm{mg} / \mathrm{L}$ were made for the Chlorpyrifos. The extract peaks appearing in the chromatogram were identified with the help of already standardized curve and the concentration pesticide residue determined.

\section{Results}

\subsection{Identification of the Isolates}


Three morphologically distinguishable bacterial colonies were observed on the mineral salt agar containing Chlorpyrifos pesticide. The results of morphological, cultural and biochemical tests carried out are shown in Table 1. The three isolates were identified as Pseudomonas aeruginosa, Serretia marcescens and Klebsiella oxytoca.

\subsection{Growth of the Isolates and Biodegradation of Chlorpyrifos in Liquid Culture}

The result of the growth response of the isolates in the presence of Chlorpyrifos showed that all the isolates utilized the insecticide as the only carbon and energy source. Pseudomonas aeruginosa showed maximum growth in 10 days, while Klebsiella oxytoca and Serretia marcescens recorded highest growth in 6 days incubation (Figure 1a-c).

Table 1. Morphological, Cultural and Biochemical Characteristics of the Isolates.

\begin{tabular}{|c|c|c|c|}
\hline Tests & Isolate 1 & Isolate 2 & Isolate 3 \\
\hline Colony Morphology & $\begin{array}{l}\text { Circular, Smooth Whitish, } \\
\text { Entire, Convex, Translucent } \\
\text { looking colonies }\end{array}$ & $\begin{array}{c}\text { Circular, Dry, Cream } \\
\text { Undulate, Flat, Opaque } \\
\text { looking colonies }\end{array}$ & $\begin{array}{l}\text { Circular, Moist, Cream, } \\
\text { Swarming, Slighlty raised, } \\
\text { Opaque looking colonies }\end{array}$ \\
\hline Gram's Reaction & - /short rods & - /short rods & - /short rods \\
\hline Methyl red & - & - & - \\
\hline Voges-Proskauer & - & + & - \\
\hline Indole & - & + & + \\
\hline Motility & + & - & + \\
\hline Citrate & + & + & + \\
\hline Oxidase & + & - & - \\
\hline Nitrate & + & + & - \\
\hline Starch & - & - & - \\
\hline Urease & - & + & - \\
\hline $\mathrm{H}_{2} \mathrm{~S}$ & - & - & - \\
\hline $\begin{array}{l}\text { Growth on } \\
\text { MacConkey }\end{array}$ & $+/ \mathrm{NLF}$ & $+/ \mathrm{LF}$ & $+/ \mathrm{NLF}$ \\
\hline Glucose Fermentation & - & $\mathrm{A} / \mathrm{G}$ & $\mathrm{A} / \mathrm{G}$ \\
\hline Sucrose & - & $\mathrm{A} / \mathrm{G}$ & $\mathrm{A} / \mathrm{G}$ \\
\hline Maltose & - & A & A \\
\hline Mannitol & - & A & A \\
\hline Lactose & - & + & - \\
\hline Fructose & + & - & - \\
\hline $\mathrm{NaCl}(2-5 \%)$ & + & + & + \\
\hline Identity & Pseudomonas aeruginosa & Serretia marcescens & Klebsiella oxytoca. \\
\hline
\end{tabular}

Key: $\mathrm{A} / \mathrm{G}=\mathrm{Acid} / \mathrm{Gas}$,

$\mathrm{NLF}=$ Non lactose fermenter,

$\mathrm{LF}=$ Lactose fermenter 


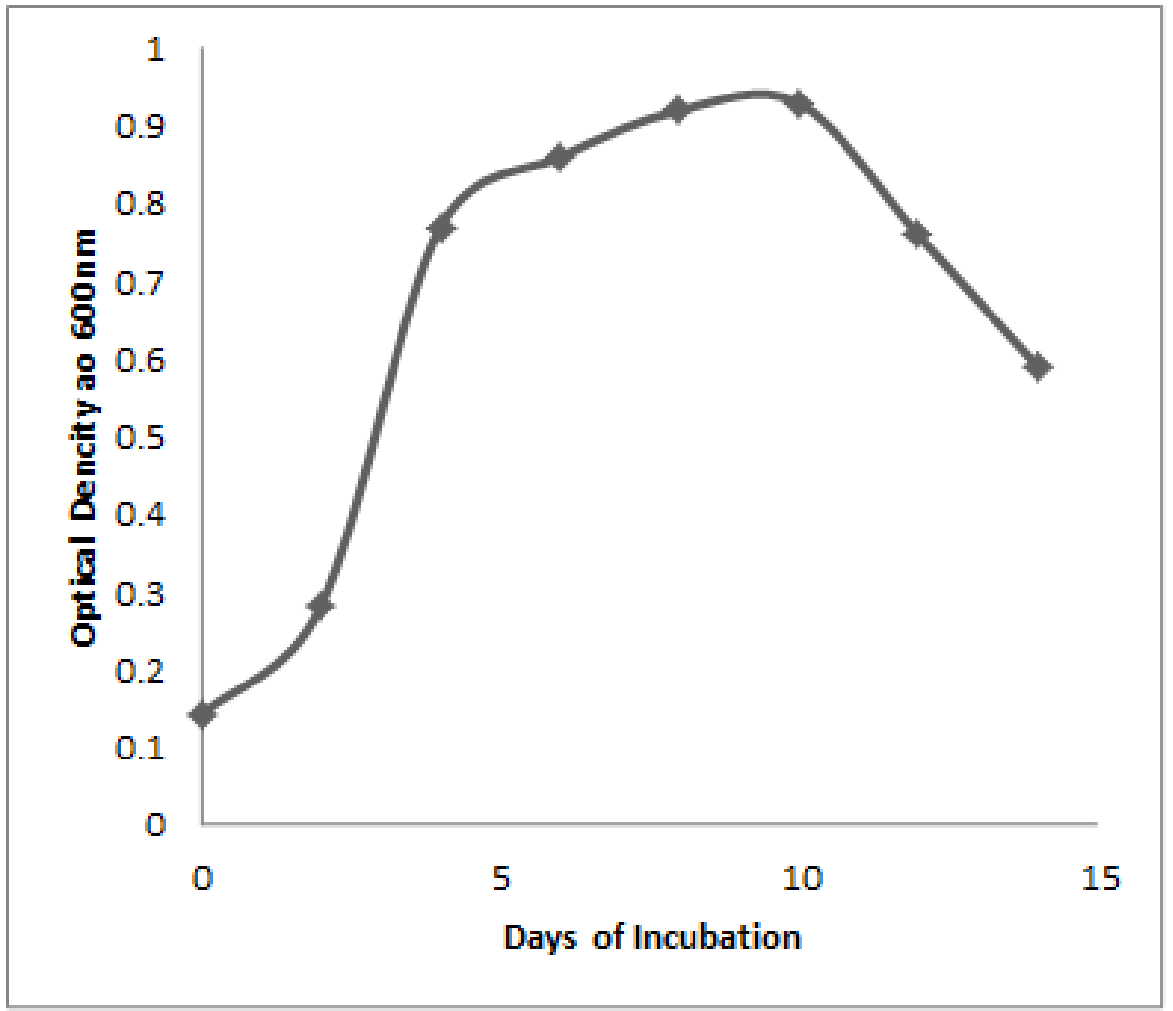

Figure 1a. Growth response of Pseudomonas aeruginosa in the presence of Chlorpyrifos pesticide.

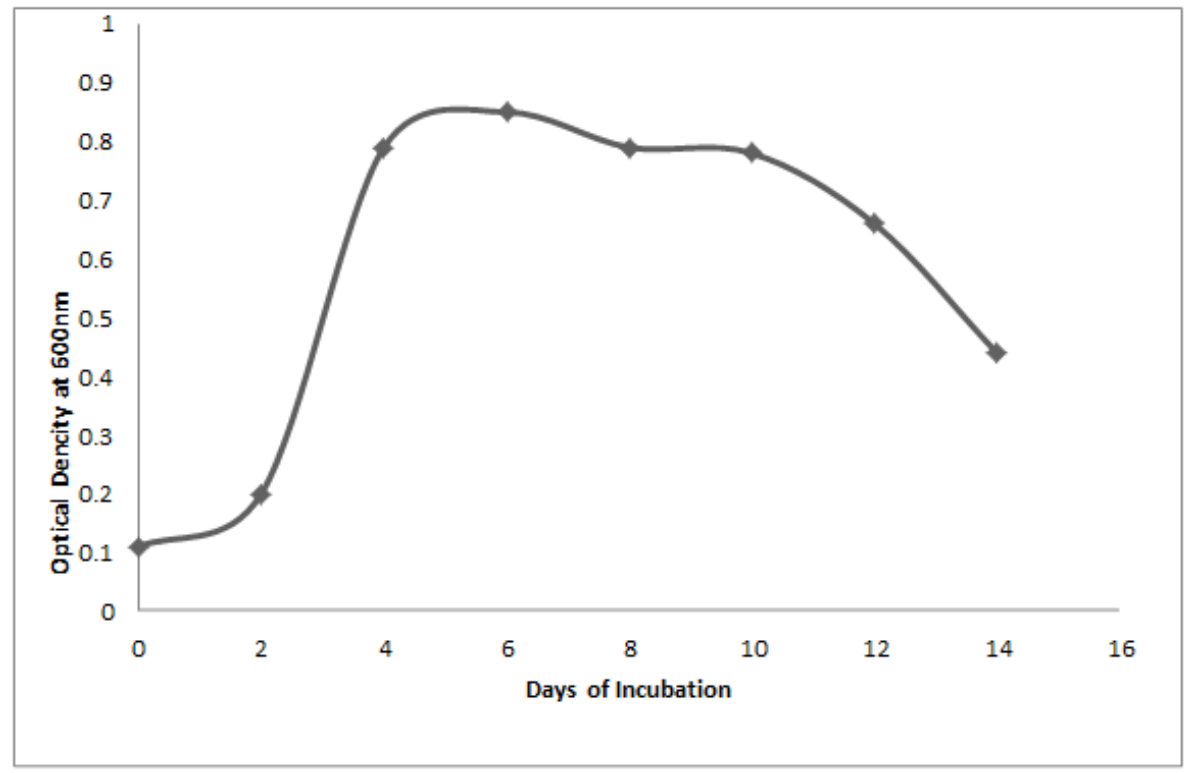

Figure 1b. Growth response of Klebsiella oxytoca in the Presence of Chlorpyrifos Pesticide 


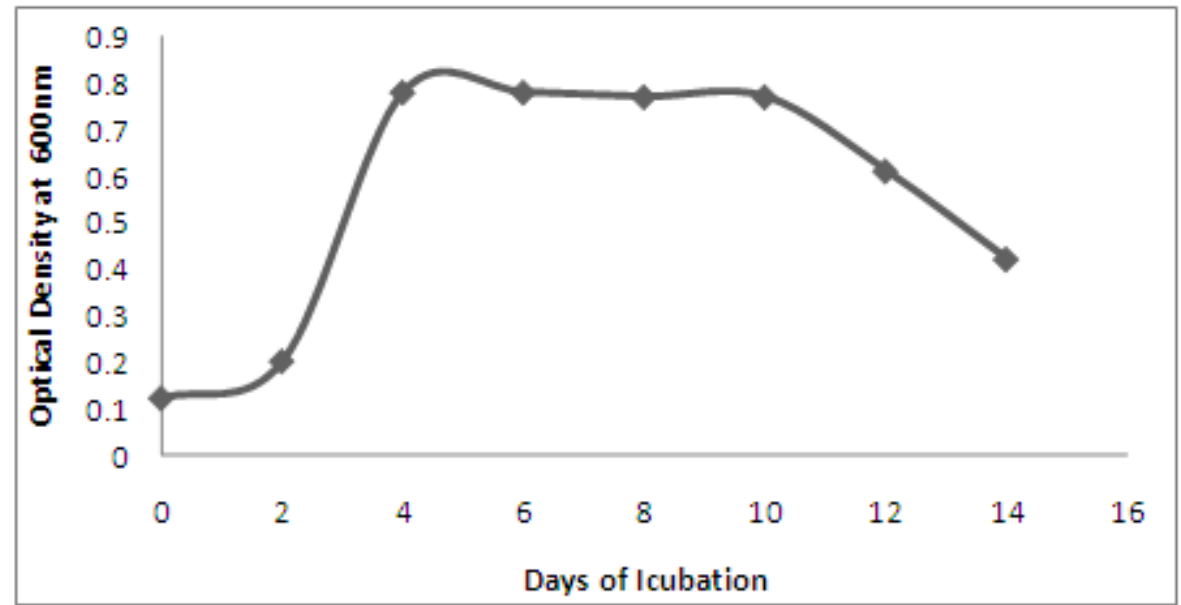

Figure 1c. Growth response of Serretia marcescens in the Presence of Chlorpyrifos Pesticide

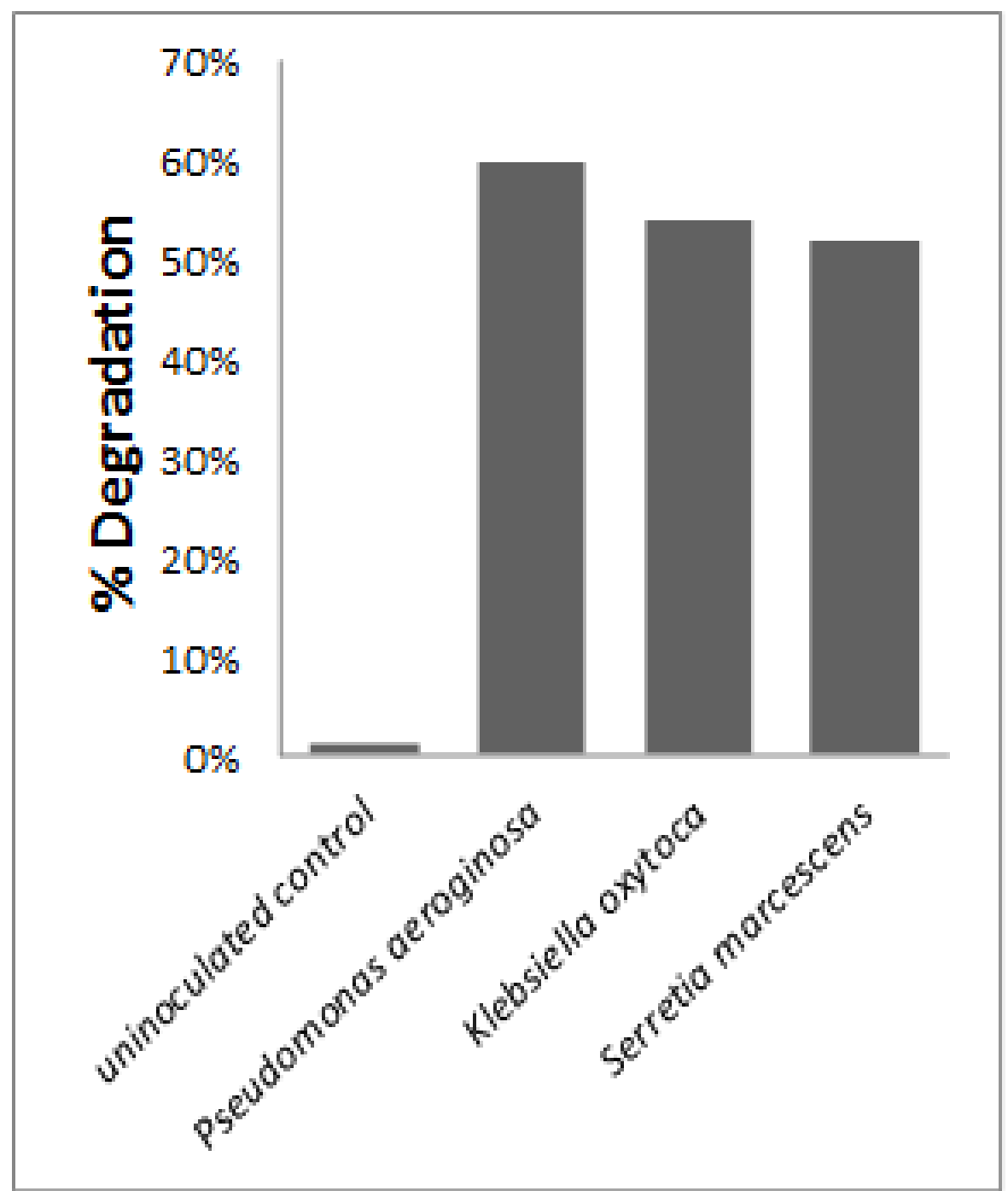

Figure 2. Percentage degradation of Chlorpyrifos by the isolates after 14days incubation period 


\section{Discussion}

In this study, three different bacteria isolated from agricultural soil, are species whose actions were reflected in significant pesticide depletion. All of the isolates are Gram negative bacteria, two of them belong to the family Enterobacteriaceae. The result obtained in this study were in agreement with earlier reports that indicated the involvement of different species of Gram negative bacteria, especially the members of Enterobacteriaceae in the degradation of organophosphorous insecticides like Chlorpyrifos ${ }^{12}$. Many pure and mixed Chlorpyrifos transforming cultures have been isolated from a variety of sources, and majority of them are cultures of Gram negative organisms ${ }^{14}$. Bioremediation of Chlorpyrifos by Pseudomonas aeruginosa using scale up technique was earlier reported by Fulekar and Geetha (2008). It was previously reported by Fulekar (2008) that Pseudomonas aeruginosa was the most common Gram negative bacterium found in soil and this bacterium has been found to have the potential to degrade Chlorpyrifos. Rani et al., (2008) isolated Serratia sp, Klebsiella sp, Providencia $s p$ and Bacillus sp implicated in the degradation of Chlorpyrifos. Munazza et al., (2005) and Furham et al (2013) also isolated Klebsiella $s p$ capable of degrading Chlorpyrifos from soil.

Among the three bacteria isolates, Pseudomonas aeruginosa showed the highest Chlorpyrifos degrading capacity $(60 \%$ reduction). This further affirms the claim made by Fulekar (2008); that Pseudomonas aeruginosa is the most Gram negative bacteria in the soil with Chlorpyrifos degrading potential. The result of the study showed that the concentration of uninoculated control was reduced from $20 \mathrm{mg} / 1$ to $19.80 \mathrm{mg} / 1$ ( $1 \%$ reduction). This reduction could be traced to the fact that once Chlorpyrifos is applied to the soil, it may be exposed to photodegradative conditions either directly or indirectly ${ }^{9}$. The decrease might also be as a result of volatilization exhibited by pesticides.

\section{Conclusions}

In the present study, three isolates capable of utilizing Chlorpyrifos as the only source of carbon and energy were identified. Biodegradation of pesticides by microorganisms is an effective means of preventing environmental pollution. Result of this study showed that the isolates (Pseudomonas aeruginosa, Klebsiella oxytoca and Serretia marcescens) can remove up to $50 \%$ Chlorpyrifos from the medium; hence they may be used for bioremediation of Chlorpyrifos contaminated soil, water or industrial effluents.

\section{REFERENCES}

[1] Eisler, R (2000). Handbook of Chemical Risk Assessment, Health Hazards to Humans, Plantand Animals 2: Organics Lewis Publishers, Washington D.C. p 883-902.
[2] Fulekar, M.H. (2008). UGC Major Research Project "Development of Bioremediation Technology for Pesticide Industrial Wastes using Novel Cow Dung Microorganisms in Sequence Biological Reactor and Two Phase Partitioning Bioreactor"

[3] Fulekar, M.H. and Geetha, M. (2008).Bioremediation of Chlorpyrifos by Pseudomonas aeruginosa using scale up technique. Journal of Applied Bioscience, 12: 657-660.

[4] Furhan, M.;Khan, A.U.; Wahid, A.; Ali,A.S. and Ahmed, F.(2013). Potential of Indigenous Klebsiella sp for Chlorpyrifos biodegradation. Pakistan Journal Science 65(1) 133-138.

[5] Gilani, S.T.S.; Ageen, M.; Shah. H. and Raza, S. (2010). Chlorpyrifos degradation in soil and its effect on soil microorganisms. Journal of Animal and Plant Sciences, 20(2) 99-102.

[6] Li, X.; He, J.; and Li, S. (2007). Isolation of Chlorpyrifos Degrading Bacterium, Shengomonas $s p$, strain DSP-2 and Cloning of the MPD Gene. Research Microbiology, 158: 143-149.

[7] Mohan, S.V.; Sirisha, K. and Rao, N.C. (2004). Degradation of Chlorpyrifos contaminated soil by Bioshurry Reactor operated in Sequencing Batch Mode. Bioprocess Monitoring. Journal of Hazard Matter, 116:39-48.

[8] Munazza, A.; Nusrat, J.; Shahida, A. and Sheikh, A.R. (2005). Chlorpyrifos resistant bacteria from Pakistani soils: Isolation, Identification, Resistance profile and Growth Kinetics. Pak. J. Bot. 37(2): 382-388.

[9] Racke, K.D. (1993). Environmental fate of Chlorpyrifos. Review in Environmental Contamination and Toxicology.131:1-150.

[10] Rani, S.M.;Lakshim, K.V.; Devi, S.P.; Madlian, F. and Aruna, K. (2008). Isolation and Characterization of Chlorpyrifos Degrading Bacteria from Agricultural Soil and its Growth Response. African Journal of Microbiology 2:26-31.

[11] Singh, B.K.; Walker, A.; Morgan, A.J. and Wright, D.J. (2003). Effects of soil $\mathrm{pH}$ on the Biodegrading of Bacterium. Applied Environmental Microbiology, 9: 5198-5206.

[12] Singh, B.K.; Walker, A.; Morgan, A.J. and Wright, D.J. (2004). Microbial Degradation of Chlorpyrifos by Enterobacterstrain B-14 and its use in Bioremediation of Contaminated soil. Applied Environmental Microbiology, 70: 4855-4863.

[13] Sumit, K. (2004).Bioremediation of Chlorpyrifos by Bacteria Isolated from the Cultivated Soils. International Journal of Pharms and Biosciences, 2: 359-366.

[14] Topp,E.; Zhu, H.;Nour, s.m.; Houost, S.; Lewis,M. and Cuppels, D.(2000). Characterisation of an Atrazine Degrading Pseudaminobacter sp. isolated from Canadian and French soil. Applied Fnviron. Microbial, 66(7): 2773-2782

[15] Yang,C.; Liu, N.; Guo, X. and Qiao, C. (2006). Cloning of mpd gene from a Chlorpyrifos degrading bacterium and use of this strain in bioremediation of contaminated soil. FEMS Microbiology Letter 265: 118-125.

[16] Zhu, J.; Zheo, Y. and Qiu, J. (2010). Isolation and Application of a Chlorpyrifos degrading Bacillus licheniformis ZHU-1. African Journal of Microbiology Research, 4(24): 2716-2719. 
[17] Mbachu, A.E., Onochie, C.C. Agu, K.C. Okafor O.I. and Awah N.S. (2014). Hydrocarbon Degrading Potentials Of Indigenous Bacteria Isolated From Auto-Mechanic Workshops at Mgbuka-Nkpor, Nigeria. Journal of Global Biosciences, 3(1): 321-326

[18] Agu, K.C., Ogbue, M.O. Abuchi, H.U. Onunkwo, A.U. Chidi-Onuorah, L.C. and Awah, N.S. (2013). Lipase Production by Fungal Isolates from Palm Oil-Contaminated
Soil in Awka Anambra State, Nigeria. International Journal of Agriculture and Biosciences, 2(6): 386-390.

[19] Agu, K.C., Orji, M.U., Onuorah, S.C., Egurefa, S.O., Anaukwu, C.G., Okafor, U.C., Awah, N.S., Okafor, O.I., Mbachu, A.E. and Anyaegbunam, B.C. (2014). Influence of Solid Waste Dumps Leachate on Bacteriological and Heavy Metals Contamination of Ground Water in Awka. American Journal of Life Science Researches, 2 (4): 450-457. 